\title{
Nocardioides alkalitolerans sp. nov., isolated from an alkaline serpentinite soil in Korea
}

\author{
Jung-Hoon Yoon, In-Gi Kim, Mi-Hwa Lee, Choong-Hwan Lee \\ and Tae-Kwang Oh \\ Korea Research Institute of Bioscience and Biotechnology (KRIBB), PO Box 115, Yusong, \\ Taejon, Korea
}

Correspondence

Jung-Hoon Yoon

jhyoon@kribb.re.kr
Four Gram-positive, rod- or coccus-shaped bacterial strains, KSL-1 ${ }^{\top}, \mathrm{KSL}-9, \mathrm{KSL}-10$ and $\mathrm{KSL}-12$, were isolated from an alkaline serpentinite soil in Korea, and their taxonomic positions were investigated in a polyphasic study. The four strains exhibited no difference in their 16S rRNA gene sequences. Phylogenetic analyses based on 16S rRNA gene sequences showed that the four strains were phylogenetically affiliated to the genus Nocardioides. The four strains had cell-wall peptidoglycan based on LL-diaminopimelic acid as the diamino acid, indicating wall chemotype I. The predominant menaquinone detected in the four strains was $\mathrm{MK}-8\left(\mathrm{H}_{4}\right)$. The major fatty acid components were iso- $\mathrm{C}_{16: 0}, 10-$ methyl- $\mathrm{C}_{18: 0}, \mathrm{C}_{18: 1} \omega 9 c$ and $\mathrm{C}_{17: 1} \omega 6 \mathrm{c}$. The DNA G +C contents were 72.4-73.6 mol\%. The four strains exhibited 16S rRNA gene sequence similarity levels of $94 \cdot 0-96 \cdot 3 \%$ to the type strains of Nocardioides species with validly published names. DNA-DNA relatedness levels between the four strains were $85-91 \%$. On the basis of phenotypic properties, phylogenetic distinctiveness and genotypic relatedness, strains $\mathrm{KSL}-1^{\top}$, KSL-9, KSL-10 and KSL-12 were classified in the genus Nocardioides as members of a novel species, Nocardioides alkalitolerans sp. nov. The type strain is strain $\mathrm{KSL}-1^{\top}\left(=\right.$ KCTC $\left.19037^{\top}=\mathrm{DSM} 16699^{\top}\right)$.
The genus Nocardioides was proposed by Prauser (1976) with a single species, Nocardioides albus, and at present it comprises 11 species with validly published names. Nocardioides species have been isolated from a variety of habitats, including soils (Prauser, 1976, 1984; O’Donnell et al., 1982; Suzuki \& Komagata, 1983), herbage (Collins et al., 1994), an oil shale column (Yoon et al., 1997), industrial wastewater (Yoon et al., 1999), water from hypersaline lakes (Lawson et al., 2000), groundwater (Yoon et al., 2004) and tidal flats (Yi \& Chun, 2004a, b). N. albus, Nocardioides luteus, Nocardioides simplex and Nocardioides jensenii were isolated from a variety of soils from different parts of the world (Prauser, 1976, 1984; O'Donnell et al., 1982; Suzuki \& Komagata, 1983). Recently, in the course of screening micro-organisms from an alkaline serpentinite soil (approximate $\mathrm{pH} 9 \cdot 0-10 \cdot 0$ ) in Korea, many bacterial strains were isolated and characterized taxonomically. Of these isolates, four Nocardioides-like strains, KSL- $1^{\mathrm{T}}$,

Published online ahead of print on 5 November 2004 as DOI 10.1099/ ijs.0.63374-0.

The GenBank/EMBL/DDBJ numbers for the 16S rRNA gene sequences of strains $\mathrm{KSL}-1^{\top}, \mathrm{KSL}-9, \mathrm{KSL}-10$ and $\mathrm{KSL}-12$ are AY633969-AY633972, respectively.

A full table of fatty acid compositions is available as supplementary data in IJSEM Online.
KSL-9, KSL-10 and KSL-12, are described in this paper. Accordingly, the aim of the present work was to determine the exact taxonomic positions of the four strains by a polyphasic taxonomic characterization.

Strains KSL- ${ }^{\mathrm{T}}$, KSL-9, KSL-10 and KSL-12 were isolated by the standard dilution plating technique at $30^{\circ} \mathrm{C}$ on tenfold-diluted nutrient agar (NA; Difco) with $\mathrm{pH}$ adjusted to $10 \cdot 0$. To investigate their morphological, physiological and biochemical characteristics, the four strains were routinely cultivated at $30^{\circ} \mathrm{C}$ on twofold-diluted NA with $\mathrm{pH}$ adjusted to $9 \cdot 0$. Cell morphology was examined by light microscopy (Nikon E600) and transmission electron microscopy (TEM). Presence of flagella was examined by TEM using cells from exponentially growing cultures. The Gram reaction was determined by using the bioMérieux Gram stain kit according to the manufacturer's instructions. The $\mathrm{pH}$ range for growth was determined in twofolddiluted nutrient broth (NB; Difco) which had been adjusted to various $\mathrm{pH}$ values (initial $\mathrm{pH} 4 \cdot 0-12 \cdot 0$ at intervals of $0.5 \mathrm{pH}$ units). Prior to sterilization the $\mathrm{pH}$ of twofold-diluted $\mathrm{NB}$ was adjusted to various levels by the addition of $\mathrm{Na}_{2} \mathrm{CO}_{3}$ (below $\mathrm{pH} 10 \cdot 5$ ) or $\mathrm{KOH}$ (above $\mathrm{pH} 10 \cdot 5)$. Growth at various temperatures $\left(4-40{ }^{\circ} \mathrm{C}\right)$ was

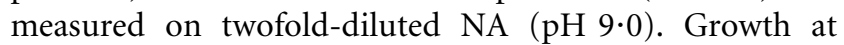
various $\mathrm{NaCl}$ concentrations was investigated in trypticase soy broth (Difco) lacking $\mathrm{NaCl}$ and in trypticase soy broth. 
Growth under anaerobic conditions was determined after incubation in an anaerobic chamber with twofold-diluted NA ( $\mathrm{pH} 9 \cdot 0)$ that had been prepared anaerobically using nitrogen. Catalase and oxidase activities and hydrolysis of casein, gelatin, hypoxanthine, starch, Tweens 20, 40, 60 and 80 , tyrosine, urea and xanthine were determined as described by Cowan \& Steel (1965). Hydrolysis of aesculin and nitrate reduction were studied as described previously (Lanyi, 1987). Enzyme activity was determined by using the API ZYM system (bioMérieux). Utilization of various substrates as sole carbon and energy sources was determined as described by Shirling \& Gottlieb (1966).

Cell biomass for cell-wall and isoprenoid quinone analyses and for DNA extraction was obtained from cultivation in twofold-diluted $\mathrm{NB}\left(\mathrm{pH} \mathrm{9 \cdot 0)}\right.$ ) at $30^{\circ} \mathrm{C}$. Isoprenoid quinones were analysed as described by Komagata \& Suzuki (1987) using reversed-phase HPLC. Chromosomal DNA isolation and purification were performed according to the method described by Yoon et al. (1996), with the exception that RNase T1 was used together with RNase A to minimize contamination with RNA. For fatty acid methyl ester (FAME) analysis, cell mass of the four strains was harvested from agar plates after incubation for 7 days on twofolddiluted NA ( $\mathrm{pH} \mathrm{9.0)}$ at $30^{\circ} \mathrm{C}$. FAMEs were extracted and prepared according to the standard protocol of the MIDI/ Hewlett Packard Microbial Identification System (Sasser, 1990). The DNA G $+C$ content was determined by the method of Tamaoka \& Komagata (1984) with the modification that DNA was hydrolysed and the resultant nucleotides were analysed by reversed-phase HPLC. The $16 \mathrm{~S}$ rRNA gene was amplified by PCR using two universal primers as described previously (Yoon et al., 1998). Sequencing of the amplified 16S rRNA gene and phylogenetic analysis were performed as described by Yoon et al. (2004). DNA-DNA hybridization was performed fluorometrically by the method of Ezaki et al. (1989) using photobiotin-labelled DNA probes and microdilution wells. Hybridization was performed with five replicates for each sample. The highest and lowest values obtained in each sample were excluded, and DNA relatedness values quoted are the means of the remaining three values.

Strains KSL- ${ }^{\mathrm{T}}$, KSL-9, KSL-10 and KSL-12 grew optimally at $25-30^{\circ} \mathrm{C}$ and $\mathrm{pH} 7 \cdot 0-9 \cdot 0$; they grew relatively well at $\mathrm{pH} 11 \cdot 0$, and weakly at $\mathrm{pH} 12 \cdot 0$. The four strains were similar in most phenotypic characteristics. Gelatin was hydrolysed by strains KSL- $1^{\mathrm{T}}$, KSL-10 and KSL-12, but not by strain KSL-9. Strains KSL-9 and KSL-12 grew at $\mathrm{pH} 5 \cdot 0$, but the other two strains did not. Other phenotypic characteristics are shown in Table 1 or given in the species description.

Strains KSL- ${ }^{\mathrm{T}}$, KSL-9, KSL-10 and KSL-12 contained LLdiaminopimelic acid as the diagnostic diamino acid in the cell wall, which is characteristic of wall chemotype I sensu Lechevalier \& Lechevalier (1970). The four strains contained a tetrahydrogenated menaquinone with eight isoprene units $\left[\mathrm{MK}-8\left(\mathrm{H}_{4}\right)\right]$ as the predominant isoprenoid quinone.
The four strains had similar fatty acid profiles that contained large amounts of branched, unsaturated, straight-chain and 10-methyl fatty acids; the major fatty acids were iso- $\mathrm{C}_{16: 0}$, 10-methyl- $\mathrm{C}_{18: 0}, \mathrm{C}_{18: 1} \omega 9 c$ and $\mathrm{C}_{17: 1} \omega 6 c$ (see supplementary table in IJSEM Online). These fatty acid profiles were generally similar to those of Nocardioides species described previously (Yoon et al., 1997, 2004; Lawson et al., 2000; Yi \& Chun, 2004a). However, there were some differences in the contents of some fatty acids, particularly iso- $\mathrm{C}_{16: 0}$ and 10-methyl- $\mathrm{C}_{18: 0}$, between the four strains and Nocardioides species, which may be caused by different cultivation conditions (Yoon et al., 1997, 2004; Lawson et al., 2000; Yi \& Chun, 2004a, b). The DNA G + C contents of strains KSL- $1^{\mathrm{T}}$, KSL-9, KSL-10 and KSL-12 were $72 \cdot 4$, $73 \cdot 6,73 \cdot 2$ and $73 \cdot 2 \mathrm{~mol} \%$, respectively.

The 16S rRNA gene sequences of strains KSL- $1^{\mathrm{T}}$, KSL-9, KSL-10 and KSL-12 determined in this study comprised 1473 nucleotides, respectively, representing approximately $96 \%$ of the Escherichia coli 16S rRNA gene sequence. The $16 \mathrm{~S}$ rRNA gene sequences of the four strains were identical. As shown in the phylogenetic tree based on the neighbourjoining algorithm, the four strains formed a distinct evolutionary lineage within the radiation of the cluster comprising Nocardioides species (Fig. 1). Similar tree topology was found in the tree generated with the maximumlikelihood algorithm (data not shown). Levels of $16 \mathrm{~S}$ rRNA gene sequence similarity between the four strains and the type strains of all Nocardioides species with validly published names ranged from $94.0 \%$ (with Nocardioides plantarum) to $96 \cdot 3 \%$ (with $N$. jensenii). Sequence similarities to all other taxa included in the phylogenetic analysis were $<94.4 \%$ (with Marmoricola aurantiacus DSM $12652^{\mathrm{T}}$ ) (Fig. 1). DNA-DNA relatedness levels between strains KSL- ${ }^{\mathrm{T}}$, KSL-9, KSL-10 and KSL-12 were $85-91 \%$, indicating that the four strains are members of the same genomic species (Wayne et al., 1987).

Comparative 16S rRNA gene sequence analysis suggests the genus Nocardioides as a possible classification for the four strains. The chemotaxonomic data are in agreement with the result of the phylogenetic classification based on $16 \mathrm{~S}$ rRNA gene sequences. In particular, the predominant menaquinone type and cellular fatty acid profile distinguish the four strains and Nocardioides species from other related genera of the family Nocardioidaceae (Miller et al., 1991; Tamura \& Yokota, 1994; Park et al., 1999; Urzì et al., 2000; Wang et al., 2001). The four strains are similar phylogenetically and genetically as well as phenotypically. The levels of 16S rRNA gene sequence similarity are low enough to exclude the possibility of assigning the four strains to a previously described Nocardioides species (Stackebrandt \& Goebel, 1994). The four strains are distinguishable from the other Nocardioides species by some phenotypic properties as shown in Table 1. Therefore, on the basis of phenotypic and chemotaxonomic data and phylogenetic distinctiveness, strains KSL- ${ }^{\mathrm{T}}$, KSL-9, KSL-10 and KSL-12 should be placed in the genus Nocardioides as members of 
Table 1. Differential phenotypic characteristics of Nocardioides species

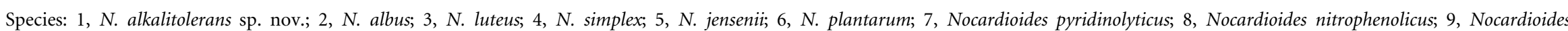

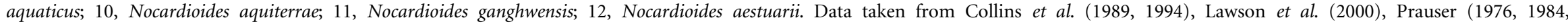

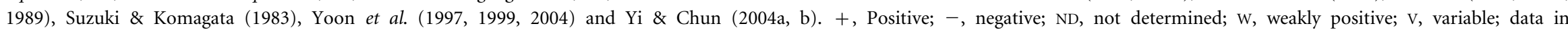

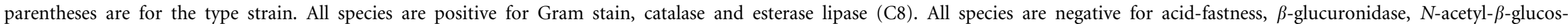
aminidase and $\alpha$-fucosidase.

\begin{tabular}{|c|c|c|c|c|c|c|c|c|c|c|c|c|}
\hline Characteristic & 1 & 2 & 3 & 4 & 5 & 6 & 7 & 8 & 9 & 10 & 11 & 12 \\
\hline Cell morphology & Rods, cocci & Hyphae & Hyphae & $\begin{array}{l}\text { Rods, } \\
\text { cocci }\end{array}$ & $\begin{array}{l}\text { Rods, } \\
\text { cocci }\end{array}$ & $\begin{array}{l}\text { Short rods, } \\
\text { cocci }\end{array}$ & $\begin{array}{l}\text { Rods, } \\
\text { cocci }\end{array}$ & Rods, cocci & $\begin{array}{l}\text { Cocci, } \\
\text { short rods }\end{array}$ & $\begin{array}{l}\text { Rods, } \\
\text { cocci }\end{array}$ & Rods & Rods \\
\hline Cell size $(\mu \mathrm{m})$ & $\begin{array}{c}0 \cdot 8-1 \cdot 0 \times \\
1 \cdot 5-2 \cdot 0\end{array}$ & $0 \cdot 5-1 \cdot 0$ & $0 \cdot 5-1 \cdot 0$ & $\begin{array}{c}1 \cdot 0-1 \cdot 2 \times \\
1 \cdot 5-6 \cdot 0\end{array}$ & $\begin{array}{c}0 \cdot 6-0 \cdot 8 \times \\
3 \cdot 0-7 \cdot 0\end{array}$ & $\mathrm{ND}$ & $\begin{array}{c}0 \cdot 5-0 \cdot 6 \times \\
1 \cdot 2-1 \cdot 6\end{array}$ & $\begin{array}{c}0 \cdot 5-0 \cdot 8 \times \\
1 \cdot 0-3 \cdot 0\end{array}$ & $\begin{array}{c}0 \cdot 9-1 \cdot 0 \times \\
0 \cdot 9-1 \cdot 4\end{array}$ & $\begin{array}{c}0 \cdot 8-1 \cdot 0 \times \\
1 \cdot 7-2 \cdot 0\end{array}$ & $\begin{array}{c}0 \cdot 4-0 \cdot 5 \times \\
0 \cdot 9-4 \cdot 5\end{array}$ & $\begin{array}{c}0 \cdot 3-0 \cdot 4 \times \\
0 \cdot 9-2 \cdot 1\end{array}$ \\
\hline Motility & - & - & - & + & - & - & + & + & - & + & - & - \\
\hline Colony colour ${ }^{*}$ & Milky-white & $\begin{array}{l}\text { Whitish to } \\
\text { faintly brownish }\end{array}$ & $\begin{array}{l}\text { Yellow to orange- } \\
\text { yellow or cream }\end{array}$ & $\begin{array}{c}\text { Yellowish } \\
\text { white }\end{array}$ & $\begin{array}{l}\text { Yellowish } \\
\text { white }\end{array}$ & $\mathrm{ND}$ & Cream & $\begin{array}{l}\text { Yellowish } \\
\text { white }\end{array}$ & Dull orange & Cream & Ivory & Ivory \\
\hline Optimal temp. $\left({ }^{\circ} \mathrm{C}\right)$ & $25-30$ & 28 & 28 & $26-37$ & ND & 25 & 35 & 30 & $16-26$ & 30 & 30 & 30 \\
\hline Nitrate reduction & + & $(-)$ & - & $(-)$ & + & - & + & - & + & + & + & - \\
\hline \multicolumn{13}{|l|}{ Hydrolysis of: } \\
\hline Aesculin & - & $(\mathrm{W})$ & + & $(+)$ & - & $\mathrm{W}$ & + & + & - & + & $\mathrm{W}$ & $\mathrm{W}$ \\
\hline Casein & + & $(+)$ & + & + & + & $+\dagger$ & + & + & + & + & + & + \\
\hline Starch & - & $(+)$ & + & $(\mathrm{w})$ & - & - & + & + & $\mathrm{w}^{\dagger}$ & - & + & - \\
\hline Gelatin & $\mathrm{V}(+)$ & $(+)$ & + & + & + & + & + & + & + & + & + & + \\
\hline Tween 80 & + & $(+)$ & + & $(+)$ & + & + & - & + & + & + & + & + \\
\hline Urea & - & $(-)$ & - & - & + & - & - & + & - & - & - & - \\
\hline Hypoxanthine & - & $(+)$ & + & $(-)$ & + & - & - & - & - & - & - & - \\
\hline Xanthine & - & $(+)$ & $-\dagger$ & $(-)$ & + & - & + & - & - & - & $\mathrm{W}$ & - \\
\hline Tyrosine & + & $(+)$ & + & $(+)$ & + & - & + & + & + & - & + & - \\
\hline \multicolumn{13}{|l|}{ Utilization of: } \\
\hline L-Arabinose & + & + & + & - & - & - & - & - & - & - & + & - \\
\hline D-Cellobiose & + & $(+)$ & + & $(-)$ & - & + & + & - & - & + & + & + \\
\hline D-Fructose & - & + & $+\dagger$ & $(-)$ & - & + & + & + & + & + & + & + \\
\hline D-Galactose & - & $(+)$ & - & $(-)$ & - & - & + & - & $-\dagger$ & + & + & + \\
\hline D-Glucose & - & + & + & + & + & $+\dagger$ & + & + & + & + & + & + \\
\hline Inositol & - & - & - & $(-)$ & - & - & + & - & $\mathrm{w} \dagger$ & - & - & - \\
\hline Lactose & - & $(-)$ & - & $(-)$ & - & - & $+\dagger$ & - & - & + & + & $\mathrm{W}$ \\
\hline
\end{tabular}


Table 1. cont.

\begin{tabular}{|c|c|c|c|c|c|c|c|c|c|c|c|c|}
\hline Characteristic & 1 & 2 & 3 & 4 & 5 & 6 & 7 & 8 & 9 & 10 & 11 & 12 \\
\hline \multicolumn{13}{|l|}{ Utilization of: } \\
\hline Maltose & $\mathrm{V}(-)$ & $\mathrm{ND}$ & $\mathrm{ND}$ & ND & $\mathrm{ND}$ & + & + & - & $\mathrm{W}$ & + & ND & $\mathrm{ND}$ \\
\hline D-Mannitol & - & + & + & - & - & - & $+\dagger$ & - & + & + & + & + \\
\hline D-Mannose & - & $(+)$ & + & $(-)$ & - & - & $+\dagger$ & $\mathrm{w} \dagger$ & - & + & + & - \\
\hline Melezitose & + & $\mathrm{ND}$ & $\mathrm{ND}$ & $\mathrm{ND}$ & $\mathrm{ND}$ & + & $\mathrm{ND}$ & - & - & - & ND & $\mathrm{ND}$ \\
\hline D-Melibiose & - & $\mathrm{ND}$ & $\mathrm{ND}$ & ND & $\mathrm{ND}$ & $\mathrm{ND}$ & - & - & $\mathrm{w}$ & - & ND & ND \\
\hline D-Raffinose & + & $\mathrm{V}(-)$ & - & - & - & - & - & - & - & - & + & $\mathrm{w}$ \\
\hline L-Rhamnose & - & + & $+\dagger$ & - & + & + & + & + & $+\dagger$ & $\mathrm{w} \dagger$ & - & - \\
\hline D-Ribose & - & $(-)$ & - & $(-)$ & - & - & + & + & - & $\mathrm{w} \dagger$ & - & - \\
\hline Sucrose & - & $\mathrm{v}(+\dagger)$ & $+\dagger$ & + & + & + & + & + & + & + & + & + \\
\hline D-Trehalose & + & $\mathrm{ND}$ & $\mathrm{ND}$ & $\mathrm{ND}$ & $\mathrm{ND}$ & + & + & + & $\mathrm{W}$ & + & ND & ND \\
\hline D-Xylose & - & + & + & - & - & + & + & + & $\mathrm{w}^{\dagger}$ & + & + & + \\
\hline \multicolumn{13}{|l|}{ API ZYM: } \\
\hline Alkaline phosphatase & + & $(+)$ & $\mathrm{V}$ & $(+)$ & $\mathrm{w}$ & - & + & + & $\mathrm{V}$ & - & + & $\mathrm{w}$ \\
\hline Esterase (C4) & + & $(+)$ & + & $(-)$ & $\mathrm{W}$ & + & - & - & $\mathrm{W}$ & - & $\mathrm{V}$ & + \\
\hline Lipase (C14) & + & $(-)$ & - & $(-)$ & - & $\mathrm{w}$ & - & - & - & - & - & - \\
\hline Leucine arylamidase & - & $(+)$ & + & $(+)$ & + & + & + & + & + & + & + & + \\
\hline Valine arylamidase & - & $(-)$ & - & $(\mathrm{w})$ & $\mathrm{V}$ & $\mathrm{w}$ & $\mathrm{w}$ & + & $\mathrm{w}$ & - & + & + \\
\hline Cystine arylamidase & - & $(-)$ & - & $(\mathrm{w})$ & - & + & - & $\mathrm{w}$ & $\mathrm{V}$ & $\mathrm{W}$ & $\mathrm{W}$ & - \\
\hline Trypsin & - & $(+)$ & + & $(+)$ & $\mathrm{W}$ & - & + & + & $\mathrm{w}$ & + & - & + \\
\hline$\alpha$-Chymotrypsin & - & $(-)$ & - & $(-)$ & - & - & - & - & - & - & - & + \\
\hline Acid phosphatase & + & $(-)$ & - & (w) & V & $\mathrm{W}$ & + & + & + & + & $\mathrm{w}$ & $\mathrm{w}$ \\
\hline $\begin{array}{l}\text { Naphthol-AS-BI- } \\
\text { phosphohydrolase }\end{array}$ & $\mathrm{W}$ & (w) & $\mathrm{v}$ & $(-)$ & $\mathrm{V}$ & + & + & + & - & + & - & $\mathrm{W}$ \\
\hline$\alpha$-Galactosidase & - & $(-)$ & - & $(-)$ & - & - & - & - & - & - & + & - \\
\hline$\beta$-Galactosidase & - & (v) & $\mathrm{V}$ & $(-)$ & - & - & - & - & - & - & + & + \\
\hline$\alpha$-Glucosidase & + & $(+)$ & $\mathrm{v}$ & $(+)$ & $\mathrm{V}$ & + & + & + & + & + & + & + \\
\hline$\beta$-Glucosidase & - & $(\mathrm{w})$ & - & $(\mathrm{w})$ & - & + & - & $\mathrm{w}$ & - & $\mathrm{W}$ & - & - \\
\hline$\alpha$-Mannosidase & - & $(-)$ & + & $(-)$ & - & - & - & - & - & - & - & - \\
\hline DNA G $+\mathrm{C}(\mathrm{mol} \%)$ & $72 \cdot 4-73 \cdot 6$ & 67 & 68 & $72-74$ & 69 & 69 & 73 & 71 & 69 & 73 & 72 & 70 \\
\hline Isolation source & Alkaline soil & Soil & Soil & Soil & Soil & Herbage & $\begin{array}{l}\text { Oil shale } \\
\text { column }\end{array}$ & $\begin{array}{c}\text { Industrial } \\
\text { wastewater }\end{array}$ & $\begin{array}{l}\text { Saline lake, } \\
\text { Antarctica }\end{array}$ & Groundwater & Tidal flat & Tidal flat \\
\hline
\end{tabular}

${ }^{*}$ Differences may be caused by different cultivation conditions.

$\dagger$ Data from Prauser $(1976,1984)$, Collins et al. (1994), Yoon et al. (1997, 1999, 2004) and Lawson et al. (2000); result differs from that obtained by Yi \& Chun (2004a). 


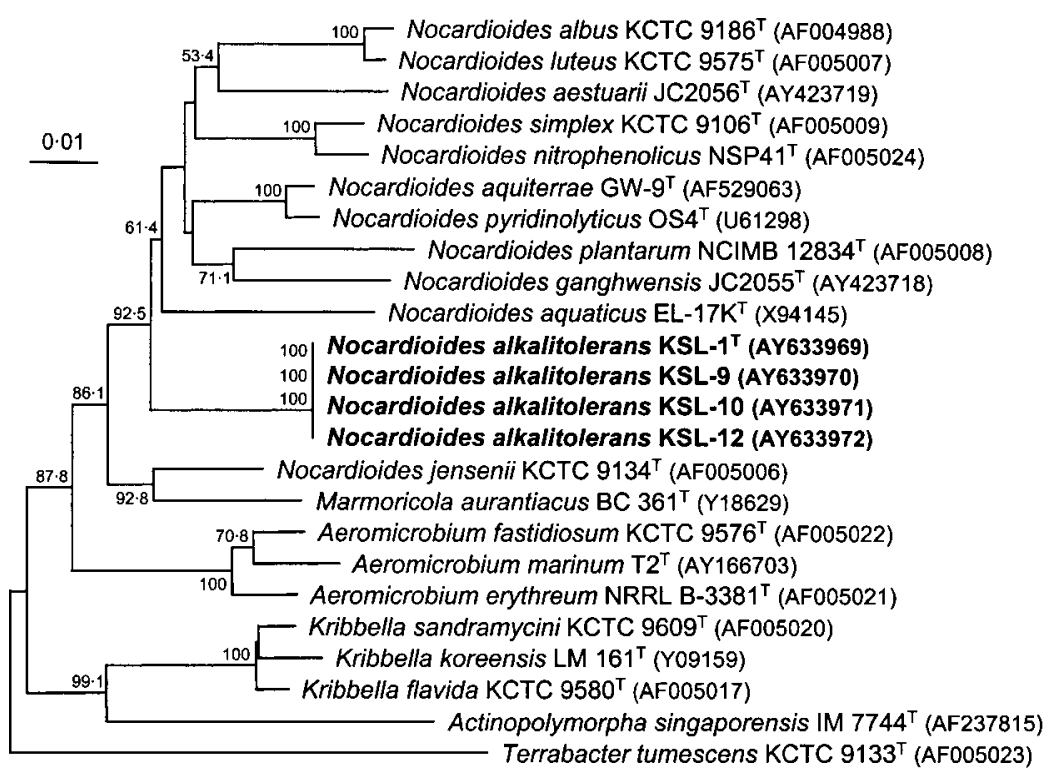

Fig. 1. Neighbour-joining phylogenetic tree based on 16S rRNA gene sequences showing the positions of strains $\mathrm{KSL}-1^{\top}, \mathrm{KSL}-9$, $\mathrm{KSL}-10$ and KSL-12 and some other related taxa. Scale bar represents 0.01 substitutions per nucleotide position. Bootstrap values (expressed as percentages of 1000 replications) of $>50 \%$ are shown at branch points. a novel species, for which the name Nocardioides alkalitolerans sp. nov. is proposed.

\section{Description of Nocardioides alkalitolerans sp. nov.}

Nocardioides alkalitolerans (al.ka.li.to'le.rans. Arabic article al the; Arabic n. qaliy ashes of saltwort; L. part. adj. tolerans tolerating; N.L. masc. part. adj. alkalitolerans referring to the ability to tolerate high $\mathrm{pH}$ ).

Cells are aerobic, non-spore-forming rods $(0 \cdot 8-1 \cdot 0 \mu \mathrm{m} \times$ $1 \cdot 5-2 \cdot 0 \mu \mathrm{m})$ in the exponential phase of growth. Cells show rod-to-coccus morphogenesis from the early exponential phase to the stationary phase. Gram-positive but Gramvariable in old cultures. Colonies are circular, smooth, glistening, convex, milky-white in colour and $0 \cdot 7-1.0 \mathrm{~mm}$ in diameter after 7 days incubation on twofold-diluted NA ( $\mathrm{pH} 9 \cdot 0)$. Neither substrate nor aerial mycelia are formed. Optimal temperature for growth is $25-30{ }^{\circ} \mathrm{C}$; grows at 4 and $34{ }^{\circ} \mathrm{C}$, but not above $35^{\circ} \mathrm{C}$. Optimal pH for growth is $7 \cdot 0-9 \cdot 0$; grows at $\mathrm{pH} 5 \cdot 5$ and $12 \cdot 0$, but growth at $\mathrm{pH} 5 \cdot 0$ is variable (no growth for type strain). Grows in the presence of $0-5 \%(\mathrm{w} / \mathrm{v}) \mathrm{NaCl}$. Oxidase-positive. Tweens 20, 40 and 60 are hydrolysed. Adonitol and D-sorbitol are not utilized. Cell-wall peptidoglycan contains LL-diaminopimelic acid as the diagnostic diamino acid. Predominant menaquinone is $\mathrm{MK}-8\left(\mathrm{H}_{4}\right)$. Major fatty acids are iso- $\mathrm{C}_{16: 0}, 10$-methyl$\mathrm{C}_{18: 0}, \mathrm{C}_{18: 1} \omega 9 c$ and $\mathrm{C}_{17: 1} \omega 6 c$. DNA $\mathrm{G}+\mathrm{C}$ content is $72 \cdot 4-73 \cdot 6 \mathrm{~mol} \%(72 \cdot 4 \mathrm{~mol} \%$ for type strain) (determined by HPLC). Other phenotypic characteristics are given in Table 1.

The type strain, KSL- $1^{\mathrm{T}}\left(=\mathrm{KCTC} 19037^{\mathrm{T}}=\mathrm{DSM} 16699^{\mathrm{T}}\right)$, was isolated from an alkaline serpentinite soil in Korea. Reference strains are KSL-9, KSL-10 and KSL-12.

\section{Acknowledgements}

This work was supported by the 21C Frontier program of Microbial Genomics and Applications (grant MG02-0401-001-1-0-0) from the Ministry of Science and Technology (MOST) of the Republic of Korea.

\section{References}

Collins, M. D., Dorsch, M. \& Stackebrandt, E. (1989). Transfer of Pimelobacter tumescens to Terrabacter gen. nov. as Terrabacter tumescens comb. nov. and of Pimelobacter jensenii to Nocardioides as Nocardioides jensenii comb. nov. Int J Syst Bacteriol 39, 1-6.

Collins, M. D., Cockcroft, S. \& Wallbanks, S. (1994). Phylogenetic analysis of a new LL-diaminopimelic acid-containing coryneform bacterium from herbage, Nocardioides plantarum sp. nov. Int J Syst Bacteriol 44, 523-526.

Cowan, S. T. \& Steel, K. J. (1965). Manual for the Identification of Medical Bacteria. London: Cambridge University Press.

Ezaki, T., Hashimoto, Y. \& Yabuuchi, E. (1989). Fluorometric deoxyribonucleic acid-deoxyribonucleic acid hybridization in microdilution wells as an alternative to membrane filter hybridization in which radioisotopes are used to determine genetic relatedness among bacterial strains. Int J Syst Bacteriol 39, 224-229.

Komagata, K. \& Suzuki, K. (1987). Lipids and cell-wall analysis in bacterial systematics. Methods Microbiol 19, 161-203.

Lanyi, B. (1987). Classical and rapid identification methods for medically important bacteria. Methods Microbiol 19, 1-67.

Lawson, P. A., Collins, M. D., Schumann, P., Tindall, B. J., Hirsch, P. \& Labrenz, M. (2000). New LL-diaminopimelic acid-containing actinomycetes from hypersaline, heliothermal and meromictic Antarctic Ekho Lake: Nocardioides aquaticus sp. nov. and Friedmanniella lacustris sp. nov. Syst Appl Microbiol 23, 219-229.

Lechevalier, M. P. \& Lechevalier, H. A. (1970). A critical evaluation of the genera of aerobic actinomycetes. In The Actinomycetales, pp. 393-405. Edited by H. Prauser. Jena: Gustav Fischer Verlag.

Miller, E. S., Woese, C. R. \& Brenner, S. (1991). Description of the erythromycin-producing bacterium Arthrobacter sp. strain NRRL 
B-3381 as Aeromicrobium erythreum gen. nov., sp. nov. Int J Syst Bacteriol 41, 363-368.

O’Donnell, A. G., Goodfellow, M. \& Minnikin, D. E. (1982). Lipids in the classification of Nocardioides: reclassification of Arthrobacter simplex (Jensen) Lochhead in the genus Nocardioides (Prauser) emend. O'Donnell et al. as Nocardioides simplex comb. nov. Arch Microbiol 133, 323-329.

Park, Y.-H., Yoon, J.-H., Shin, Y. K., Suzuki, K., Kudo, T., Seino, A., Kim, H.-J., Lee, J.-S. \& Lee, S. T. (1999). Classification of 'Nocardioides fulvus' IFO 14399 and Nocardioides sp. ATCC 39419 in Kribbella gen. nov., as Kribbella flavida sp. nov. and Kribbella sandramycini sp. nov. Int J Syst Bacteriol 49, 743-752.

Prauser, H. (1976). Nocardioides, a new genus of the order Actinomycetales. Int J Syst Bacteriol 26, 58-65.

Prauser, H. (1984). Nocardioides luteus spec. nov. Z Allg Microbiol 24, 647-648.

Prauser, H. (1989). Genus Nocardioides Prauser 1976. In Bergey's Manual of Systematic Bacteriology, vol. 4, pp. 2371-2375. Edited by S. T. Williams, M. E. Sharpe \& J. G. Holt. Baltimore: Williams \& Wilkins.

Sasser, M. (1990). Identification of Bacteria by Gas Chromatography of Cellular Fatty Acids. Newark, DE: MIDI.

Shirling, E. B. \& Gottlieb, D. (1966). Methods for characterization of Streptomyces species. Int J Syst Bacteriol 16, 313-340.

Stackebrandt, E. \& Goebel, B. M. (1994). Taxonomic note: a place for DNA-DNA reassociation and 16S rRNA sequence analysis in the present species definition in bacteriology. Int J Syst Bacteriol 44, 846-849.

Suzuki, K. \& Komagata, K. (1983). Pimelobacter gen. nov., a new genus of coryneform bacteria with LL-diaminopimelic acid in the cell wall. J Gen Appl Microbiol 29, 59-71.

Tamaoka, J. \& Komagata, K. (1984). Determination of DNA base composition by reverse-phase high-performance liquid chromatography. FEMS Microbiol Lett 25, 125-128.

Tamura, T. \& Yokota, A. (1994). Transfer of Nocardioides fastidiosa Collins and Stackebrandt 1989 to the genus Aeromicrobium as
Aeromicrobium fastidiosum comb. nov. Int J Syst Bacteriol 44, 608-611.

Urzi, C., Salamone, P., Schumann, P. \& Stackebrandt, E. (2000). Marmoricola aurantiacus gen. nov., sp. nov., a coccoid member of the family Nocardioidaceae isolated from a marble statue. Int J Syst Evol Microbiol 50, 529-536.

Wang, Y. M., Zhang, Z. S., Xu, X. L., Ruan, J. S. \& Wang, Y. (2001). Actinopolymorpha singaporensis gen. nov., sp. nov., a novel actinomycete from the tropical rainforest of Singapore. Int J Syst Evol Microbiol 51, 467-473.

Wayne, L. G., Brenner, D. J., Colwell, R. R. \& 9 other authors (1987). International Committee on Systematic Bacteriology. Report of the ad hoc committee on reconciliation of approaches to bacterial systematics. Int J Syst Bacteriol 37, 463-464.

Yi, H. \& Chun, J. (2004a). Nocardioides ganghwensis sp. nov., isolated from tidal flat sediment. Int J Syst Evol Microbiol 54, 1295-1299.

Yi, H. \& Chun, J. (2004b). Nocardioides aestuarii sp. nov., isolated from tidal flat sediment. Int J Syst Evol Microbiol 54, 2151-2154.

Yoon, J.-H., Kim, H., Kim, S.-B., Kim, H.-J., Kim, W. Y., Lee, S. T., Goodfellow, M. \& Park, Y.-H. (1996). Identification of Saccharomonospora strains by the use of genomic DNA fragments and rRNA gene probes. Int J Syst Bacteriol 46, 502-505.

Yoon, J.-H., Rhee, S.-K., Lee, J.-S., Park, Y.-H. \& Lee, S. T. (1997). Nocardioides pyridinolyticus sp. nov., a pyridine-degrading bacterium isolated from the oxic zone of an oil shale column. Int J Syst Bacteriol 47, 933-938.

Yoon, J.-H., Lee, S. T. \& Park, Y.-H. (1998). Inter- and intraspecific phylogenetic analysis of the genus Nocardioides and related taxa based on 16S rRNA gene sequences. Int J Syst Bacteriol 48, 187-194.

Yoon, J.-H., Cho, Y.-G., Lee, S. T., Suzuki, K.-I., Nakase, T. \& Park, Y.-H. (1999). Nocardioides nitrophenolicus sp. nov., a p-nitrophenoldegrading bacterium. Int J Syst Bacteriol 49, 675-680.

Yoon, J.-H., Kim, I.-G., Kang, K. H., Oh, T.-K. \& Park, Y.-H. (2004). Nocardioides aquiterrae sp. nov., isolated from groundwater in Korea. Int J Syst Evol Microbiol 54, 71-75. 